\title{
Translation and Cross-Cultural Adaptation of the Test of Infant Motor Performance to Colombian Spanish
}

\section{Traducción y adaptación transcultural del Test of Infant Motor Performance al español de Colombia Tradução e adaptação transcultural do Test of Infant Motor Performance para o espanhol colombiano}

Mónica Naranjo Ruiz, Mg.1*

Inés Gabriela Guerrero Uchima, Mg.1

María Eugenia Serrano Gómez, Mg. ${ }^{2}$

Martha Lucía Acosta Otálora, Mg. ${ }^{2}$

Mónica Yamile Pinzón Bernal, Mg. ${ }^{3}$

Luisa Matilde Salamanca Duque, Mg. ${ }^{3}$

Received: January 21, $2021 \cdot$ Accepted: November 22, 2021

Doi: https://doi.org/10.12804/revistas.urosario.edu.co/revsalud/a.10146

To cite this article: Naranjo Ruiz M, Guerrero Uchima G, Serrano Gómez ME, Acosta Otálora ML, Pinzón Bernal MY, Salamanca Duque LM. Translation and Cross-Cultural Adaptation of the Test of Infant Motor Performance to Colombian Spanish. Rev Cienc Salud. 2022;20(1): 1-17. https://doi.org/10.12804/revistas.urosario.edu.co/revsalud/a.10146

1 CITERm Research Group, Universidad Autónoma de Manizales (Colombia).

2 Universidad de la Sabana, Campus del Puente Común, Km 7 Autopista Norte de Bogotá, Chía, Cundinamarca, Colombia. Universidad de La Sabana (Colombia).

3 Universidad Autónoma de Manizales (Colombia).

Mónica Naranjo Ruiz, ORCID: https://orcid.org/0000-0002-5621-0985

Inés Gabriela Guerrero Uchima, ORCID: https://orcid.org/0000-0002-3047-574X

María Eugenia Serrano Gómez, ORCID: https://orcid.org/0000-000-24141-982

Martha Lucía Acosta Otálora, ORCID: https://orcid.org/0000-0003-4663-2196

Mónica Yamile Pinzón Bernal, oRCID: https://orcid.org/0000-0003-4678-2346

Luisa Matilde Salamanca Duque, ORCID: https://orcid.org/0000-0002-8093-0712

*Corresponding author mnaranjo@autonoma.edu.co 


\section{Abstract}

Introduction: There has been growing interest in recent years in the cross-cultural adaptation of measuring instruments for various conditions treated by physiotherapy. Validation of an instrument within a target language and culture creates a final version that is conceptually and linguistically adapted to the context but remains valid and reliable. This paper describes the process of translation and cross-cultural adaptation of the Test of Infant Motor Performance (тімг) from us English to Colombian Spanish. This was performed in accordance with international methodological guidelines. Materials and methods: A group of trained translators and field experts participated in the five stages presented herein. These stages were translation and adaptation of the instrument to Colombian Spanish, validation of its content and appearance, back-translation, revision by the original author, and, finally, a pilot test. Results: The existence of two intralingual translated and revised versions of this instrument led to a more appropriate preliminary version from conceptual, discursive, and terminological perspectives. Therefore, the adjustments made in the first stage were primarily semantic. During the second stage, field experts positively assessed the translated version and suggested adjustments to grammar, spelling, and word choices. There were no significant discursive problems during the back-translation stage so conceptual and terminological adjustments were minor. The revision stage and the pilot test were satisfactory. Conclusion: This translation and cross-cultural adaptation was successful. The Colombian Spanish version of the measure was culturally relevant and used appropriate language, yet remained a valid and reliable tool.

Keywords: Infants; newborns; motor skills; translation; reliability of results.

\section{Resumen}

Introducción: la adaptación transcultural de distintos instrumentos de medición, y para diferentes tipos de condiciones en el campo de la fisioterapia, ha sido un tema de interés en los últimos años. La validación lingüística de un instrumento a una lengua y cultura meta implica que la versión final es adaptada conceptual y lingüísticamente al contexto meta. El objetivo de este artículo es describir el proceso de traducción y adaptación transcultural al español de Colombia del Test of Infant Motor Performace (Timp) siguiendo los lineamientos metodológicos internacionales. Materiales y método: se conformó un grupo de traductores calificados y de expertos que participaron en cinco fases: traducción y adaptación al español de Colombia, validez de contenido y apariencia, retrotraducción, revisión por autora original y prueba piloto. Resultados: la posibilidad de contar con dos versiones intralinguales revisadas llevó a una versión preliminar más adecuada desde las perspectivas conceptual, discursiva y terminológica. Por lo tanto, los ajustes en esta fase se realizaron principalmente desde una perspectiva semántica. En cuanto a la segunda fase, los expertos validaron positivamente dicha versión y sugirieron cambiar algunas palabras y cuestiones ortográficas. La fase de retrotraducción y la validación no presentaron problemas discursivos, así que las adecuaciones conceptuales y terminológicas fueron mínimas. La fase de revisión y la prueba piloto fueron satisfactorias. Conclusión: este proceso de traducción y adaptación transcultural fue exitoso. La versión al español de Colombia fue apropiada culturalmente, además de ser una herramienta válida y confiable.

Palabras clave: recién nacido; destreza motora; traducción; reproducibilidad de los resultados.

\section{Resumo}

Introdução: a adaptação transcultural de diferentes instrumentos de medida e para diferentes tipos de condições no campo da fisioterapia tem sido um tema de interesse nos últimos anos. A validação linguística de um instrumento para uma língua e cultura alvo implica que a versão final seja conceitual e linguisticamente adaptada ao contexto alvo. O objetivo deste artigo é descrever o processo de tradução e 
adaptação transcultural para o espanhol colombiano do Test of Infant Motor Performace (TIMP) de acordo com as diretrizes metodológicas internacionais. Materiais e métodos: foi conformado um grupo de tradutores qualificados e especialistas que participaram em cinco fases: tradução e adaptação para o espanhol colombiano, validade de conteúdo e aparência, retrotradução, revisão pelo autor original e teste piloto. Resultados: a possibilidade de haver duas versões intralinguais revisadas levou a uma versão preliminar mais adequada do ponto de vista conceitual, discursivo e terminológico, portanto, os ajustes nesta fase foram feitos principalmente do ponto de vista semântico. Já na segunda fase, os especialistas validaram positivamente essa versão e sugeriram alterações em algumas palavras e problemas ortográficos. A fase de retrotradução e a validação não apresentaram problemas discursivos, portanto as adaptações conceituais e terminológicas foram mínimas. A fase de revisão e o teste piloto foram bem-sucedidos. Conclusão: este processo de tradução e adaptação transcultural foi favorável do ponto de vista de validade e aparência para o contexto colombiano.

Palavras-chave: recém-nascido; habilidades motoras; tradução; reprodutibilidade de resultados.

\section{Introduction}

$\mathrm{N}_{\mathrm{t}}^{\mathrm{e}}$ ewborns with low birth weight and those born prematurely are at risk of various lifethreatening conditions, including neurological deficits, heart disease, and infection (1). Preterm infants are at high risk of neurological disorders as they have suboptimal neurodevelopment compared to full-term infants. This is compounded by the need to place them in neonatal intensive care, which is highly stressful for the infant due to the premature separation from their mother and the inability to breastfeed while in an incubator. Moreover, the concurrent risk of other health conditions elevates the risk of neurological disorders (2).

The neurological risks faced by premature infants can be classified as high, medium, or low. Those with higher neurological risks suffer from higher mortality rates and are more prone to cognitive, linguistic, sensorineural, and motor impairments. Although the survival rates of preterm infants have increased due to advances in neonatology, this has led to an increased incidence of disability in those that may not previously have survived $(1,3)$.

Many of the conditions associated with neurological risk involve language deficits and deficient motor development. The latter can cause atypical movements and prevent the acquisition of basic motor functions and functionality. Cognitive deficits and learning disabilities usually become apparent during the first five years, Cerebral Palsy (ср) is the condition most strongly associated with premature birth. The degree of dysfunction arising from ср can vary. The condition is particularly likely among infants weighing less than $3 \mathrm{lbs}$. $5 \mathrm{oz}$ and born earlier than 28 weeks into the pregnancy $(4,5)$.

Early diagnosis of such conditions is vital for timely and proper intervention. Assessments and screenings for neurodevelopmental disorders are key aspects of this process. Hence, standardized instruments for the assessment of infant motor performance are paramount; 
and the Test of Infant Motor Performance (тIMP) is internationally recognized. The тімP has been used to evaluate motor performance in infants between week 34 of gestation and four months of age (6-9). Changes in scores are measured every two weeks and scores are compared to the developmental norms for the infant's current age. High levels of motor impairment found on the тімP can be indicative of several possible conditions, including сP (10).

In the field of physiotherapy, there has been increased interest in the translation and cross-cultural adaptation of medical assessment instruments in recent years. The Mapi Research Institute states that the linguistic validation of an instrument for a target culture involves its conceptual and linguistic adaptation to the context in which it will be used. The authors of the current study followed the assessment translation and validation guidelines of Beaton et al., Escobar Bravo, Balluerka et al., Muñiz et al., Valdelamar-Jiménez et al., and Garcimartin et al. (11-16).

Translation and cross-cultural adaptation are considered in this study from communicative and functional perspectives in which translators become linguistic and cultural mediators through their production of an instrument equivalent to the original. This requires collaboration between translators and field experts and rigorous methodology that is focused on obtaining a linguistically, culturally, and disciplinarily reliable final version (17).

When the original instrument comprises distinct discursive, terminological, and conceptual conditions, the cross-cultural adaptation must comply with such conditions. In this regard, the Communicative Theory of Terminology was utilized in this research as a theoretical basis from which to comprehensively address concepts and terms (18). This theory allows for the study of specialized discourse concerning its conditions of production and reception.

This paper describes the translation and cross-cultural adaptation of the TIMP from us English to Colombian Spanish to obtain an appropriate Colombian scale for the assessment of motor performance and identification of neurological risk in infants from birth to four months.

\section{Materials and methods}

Cross-cultural adaptation has been widely used in healthcare due to the great number of instruments that medical practitioners use to assess and evaluate their patients, which are usually in English, originally. This provides opportunities for researchers to conduct cross-cultural studies that benefit health professionals and their patients. Cross-cultural adaptation is an essential aspect of the translation process but the task is neither simple nor literal and requires the amalgamation of different knowledge and skills. 


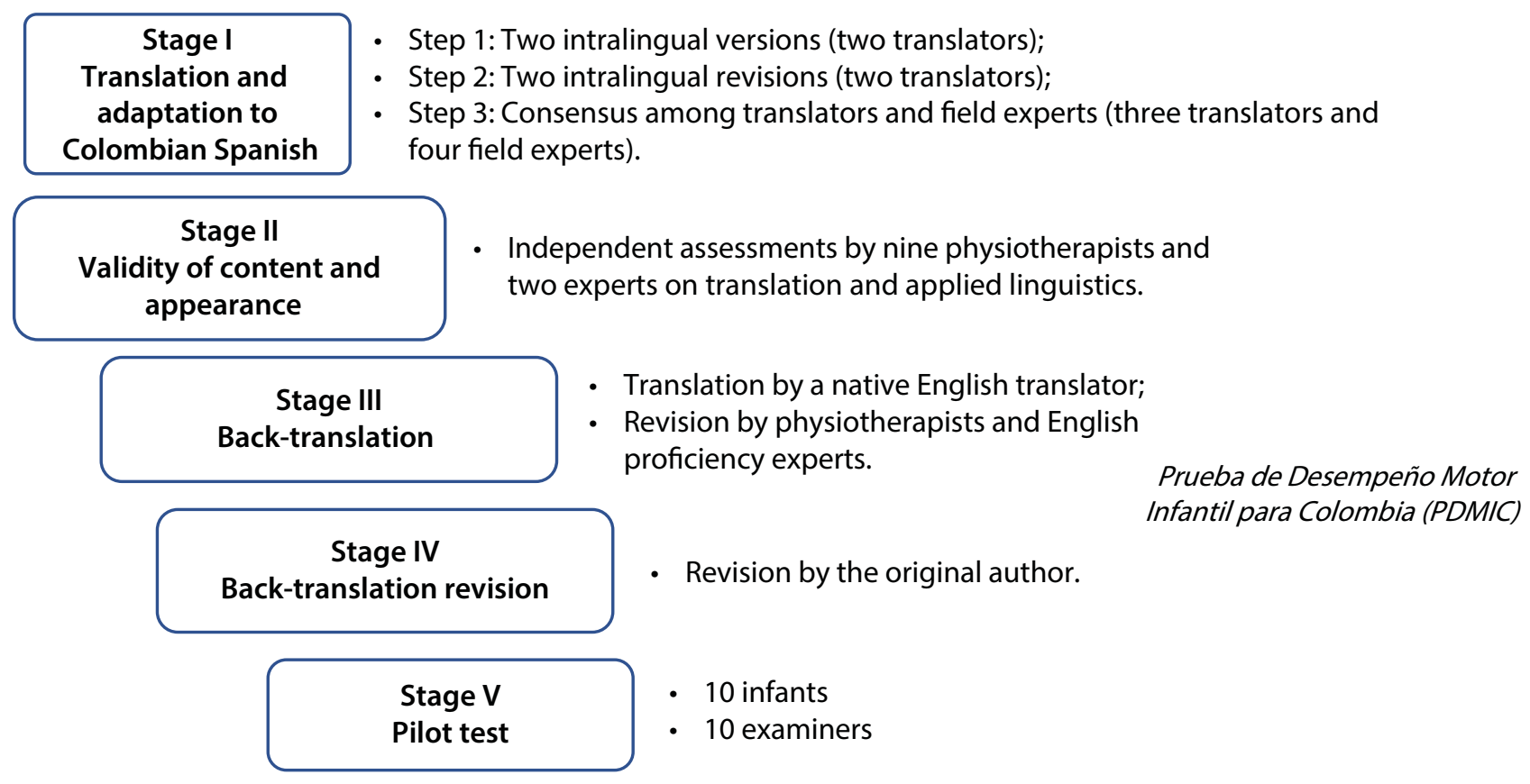

Figure 1. Stages in the Translation and Cross-Cultural Adaptation of the Test of Infant Motor Performance (TIMP)

We were granted permission to translate and adapt the тIMP to Colombian Spanish by both its original authors, Campbell et al., and by Echevarría, who generated a Spanish version for Spain $(6,19)$.

The process consisted of five stages. These were translation and adaptation of the TIMP to Colombian Spanish; validation of the Spanish content and appearance; back-translation revision; review by the original author; and a pilot test.

This study was approved by the Bioethics Committee of the Universidad Autónoma de Manizales (act 088, 2019) and by the Research Ethics Subcommittee of the Faculty of Nursing and Rehabilitation of the Universidad de La Sabana (Code Enf-23-2017, 2017).

\section{Instrument}

The TIMP was developed by a team of researchers from the University of Chicago to assess infants from 34 weeks post-conception (born prematurely) to four months from birth. Although the original instrument states that it can be used for infants from 32 weeks post-conception, it provides a more accurate assessment from 34 weeks post-conception (6). The test consists of 42 items; 13 of which assess spontaneous movements through observation, and 29 items of which are elicited by the examiner to assess developmental behaviors such as rolling over and pulling up to sit. The test follows a standardized protocol for assessment procedures and recording responses. Observational items are scored as one or zero based on the presence or absence, respectively, of the expected motor response. Elicited items are scored between zero and six, with higher scores 
for better motor responses. Gross scores are the sum of all values obtained. Z-scores are used to indicate the standard deviation from the mean. These are calculated based on preestablished normative values, allowing an infant's motor development to be described as typical (z-scores $\geq-0.5)$ or atypical (z-scores <-0.5) (20).

The TIMP has been tested by its original authors and by Spittle et al., both of whom found excellent correlation indices for reliability and validity, with scores of 0.98-0.99 for interrater reliability class correlation coefficient (ccI), with scores of 0.95 intra-rater reliability class correlation coefficient for cci, 0.89 for test-retest reliability cci, and $\mathrm{r}=0.85$ for construct validity $(6,21)$. The Alberta Infant Motor Scale (AIMS) is a well-established and proven measure of infant motor skills that can be used at any time during the child's first year. Therefore, the TIMP was compared to the AIMs in tests of three-month-old babies. The TIMP showed high concurrent validity $(r=0.64)$ in this comparison (22). Scores on the тімг have also demonstrated strong correlations with the findings of fMRI scans of the basal ganglia and white matter of preterm infants at 40 weeks chronological age, and 12 weeks corrected age (23).

Campbell and Hedeker found AIms to have high sensitivity (92\%) and specificity (76\%) and Campbell et al. reported sensitivity of $92 \%$ and specificity of $76 \%(24,7)$. They further found that AIms tests of three-month-old (corrected age) infants had a negative predictive value of $98 \%$ for a diagnosis of motor delayed motor development at 12 months of age.

The methodological procedures used in this study for translation and cross-cultural adaptation were developed in accordance with international standards that have been established to ensure equivalence between original measures and linguistically revised adaptations. The procedure comprised five stages. These are described below.

\section{Stage I: Translation and Cross-Cultural Adaptation}

The first stage comprised an intralingual translation of the тімг from Castilian Spanish to Colombian Spanish. For this purpose, two versions were created by two independent translators, both of whose mother tongue is Colombian Spanish. The purpose of this was to produce two preliminary versions that conceptually and linguistically replicated the original instrument. Although Spain and Colombia share the same official language, the social and cultural contexts differ, thus adjustments regarding cultural, idiomatic and conceptual were made. Neither translator had academic or practical experience in physical therapy. After this, two different translators independently reviewed both initial translations. To minimize errors, three translators and four experts in physiotherapy and with experience treating newborns met to discuss the two translations and develop a common version. This involved triangulation of the original English version, the two intralingual versions, and the target context in which the instrument would be utilized. The conceptual (disciplinary 
field), semantic (meaning), and pragmatic (linguistic, experiential, and contextual) dimensions of each item were analyzed and classified. The conceptual dimension was assessed by physiotherapists because of their expert knowledge. The Colombian Spanish grammar and conventions appropriate to this kind of writing and the adequacy and precision of the terminology used were considered as aspects of the semantic and pragmatic dimensions. In terms of experiential equivalence, those expressions relevant to the daily lives and cultural experiences of test users were adapted to express the same meaning in a more relevant manner within the target context. A written report was produced to document all stages of this process. The final amalgamation of the two translations, agreed upon during this meeting and discussion, was the preliminary version of the instrument in Colombian Spanish: Prueba de Desempeño Motor Infantil para-Colombia (PDMIC).

\section{Stage II: Validation of Content and Appearance}

A team of nine expert judges with a requisite post-graduate education, teaching and research experience, and neurodevelopmental training; three translators; and two applied linguists, with in-depth knowledge of English and Spanish, judged this preliminary version. Preestablished criteria were used to ensure all elements were fully assessed, and each criterion was judged through the selection of a score on a Likert scale.

Each expert conducted their quantitative and qualitative assessments independently. The criteria upon which each item was assessed were relevance, adequacy, clarity, observability, starting positions, and procedures. The rating scale for each ranged from one to four (1: totally disagree, 2 : disagree, 3 : agree and 4: totally agree) (see Table 1).

Table 1. Criteria Used by Expert Judges to Evaluate our Colombian Spanish Translation of the Test of Infant Motor Performance (TIMP)

Criterion to be evaluated

Relevance: Whether the item and its qualification are important for the evaluation of motor development in Colombian infants aged 0-4 months.

Adequacy: The capacity of each item and its qualification to properly evaluate motor development in Colombian infants aged 0-4 months.

Clarity: Whether the item and its qualification are accurate and understandable for use in the evaluation of motor development in Colombian infants aged 0-4 months.

Observability: Whether the elements assessed by the item could be observed by an external evaluator in Colombian infants aged 0-4 months (the external evaluator being a healthcare professional such as a physiotherapist or occupational therapist).

\section{Suggested question}

Do you think that this item and its qualification are important for the evaluation of motor development in Colombian infants aged 0-4 months?

Do you believe that the item and its qualification are sufficient to evaluate this aspect of motor development in Colombian infants aged 0-4 months?

Do you believe this item and its measurement would be clear and understandable to an evaluator?

Do you think that the elements to be evaluated by this item and its qualification could be observed by an external evaluator in Colombian infants aged 0-4 months? 
The means (M), standard deviations (SD), and coefficients of variation (cv) for the criteria listed above were used to determine where alterations were required, according to the following rules:

- If an item achieved high average scores ( $\mathrm{m} \geq 3.0)$ and low variability ( $\mathrm{SD}<1.0)$ on a given criterion, it was deemed to require few, or no, adjustments.

- Different scores from the prior ones demanded item adjustment.

- If an item had a cv $\geq 0.4$ in relation to its standard deviation and mean for a given criterion, it was judged to require adjustments.

The qualitative assessments consisted of additional notes and comments from the judges. The revisions made in response to the judges' evaluations resulted in the penultimate version of the Prueba de Desempeño Motor Infantil para-Colombia (PDMIC).

\section{Stages III \& IV: Back-Translation and Revision by the Original Author}

Back-translation of a translated instrument consists of translating the revised measure back to its original language to ensure no meaning or important elements have been lost. This was initially conducted by one English translator native to England, with no background in physical therapy. The resulting version was reviewed by two bilingual physical therapy experts, who evaluated the appropriateness of its terminology and its semantic coherence. The final form of the back-translated instrument was achieved once the latter were satisfied with the resulting English version of the TIMP/PDMIC. This was then sent to the original author, who assessed the back-translation to determine its concordance with the original. Dr. Campbell approved the version as a conceptually and linguistically sound, purpose-appropriate Colombian Spanish adaptation of the original instrument.

\section{Stage V: Pilot Test}

A pilot test was conducted with a group of ten physiotherapists with experience and training in neurodevelopment, neurorehabilitation, and child development. These were representative of the target population who will use the test. The purpose of the pilot was to empirically verify the instrument's equivalence, clarity, feasibility, and acceptability.

Probing techniques were used to test all items according to the following five criteria: (a) understanding of the instructions, (b) understanding of the items, (c) understanding of the scoring options, (d) time taken to administer the test and administration difficulties. For the first four criteria, the participant physiotherapists rated the adequacy of the test on a scale from 1 to 4: 1 for very inadequate, 2 for inadequate, 3 for adequate, and 4 for very adequate. Difficulty 
levels were also rated from 1 to $4: 1$ for very difficult, 2 for fairly difficult, 3 for mildly difficult, and 4 for not difficult. A meeting among researchers and linguists was held for consensus.

\section{Results}

uring the first stage of translation and adaptation, the authors conducted a comprehensive analysis and classification of the items on the TIMP from both a linguistic and a disciplinary perspective; considering the semantic, idiomatic, experiential, and conceptual components of the test. Most changes were relatively minor conceptual and contextual aspects due to cultural differences in the use of terminology and professional practice in the field of neurodevelopment in Colombia. The items were then deemed equivalent to the original.

The majority of adjustments to items were for semantic equivalence, followed by conceptual and experiential equivalence. Adjustments to various aspects were sometimes necessary to achieve equivalence in the same item. This was the case for the elicited items $15,16,22,23 / 34,38 / 39$, which required adjustments for three types of equivalence. After this first stage, the authors tested for the Colombian context to ensure there were no uncertainties or ambivalence in the reading, monitoring, and execution of procedures when the test was administered (Table 2).

Table 2. Example Items from the Test of Infant Motor Performance (TIMP) Translated and Adapted to Colombian Spanish, with English-Spanish Correspondences

\begin{tabular}{llll}
\hline \multicolumn{1}{c}{ Item } & \multicolumn{1}{c}{ Item in English } & \multicolumn{1}{c}{$\begin{array}{c}\text { Item translated and } \\
\text { adapted to Colombian } \\
\text { Spanish }\end{array}$} & \multicolumn{1}{c}{ Equivalence type } \\
\hline Observed item 5 & $\begin{array}{l}\text { Touches objects or surfac- } \\
\text { es to the left }\end{array}$ & $\begin{array}{l}\text { Toca objetos o superficies } \\
\text { con la mano izquierda }\end{array}$ & $\begin{array}{l}\text { Semantic and concep- } \\
\text { tual correspondence }\end{array}$ \\
\hline Elicited item 15 & $\begin{array}{l}\text { Head control -supported } \\
\text { sitting }\end{array}$ & $\begin{array}{l}\text { control cefálico - sedente } \\
\text { con apoyo }\end{array}$ & $\begin{array}{l}\text { Semantic, conceptual, } \\
\text { and experiential cor- } \\
\text { respondence }\end{array}$ \\
\hline $\begin{array}{llll}\text { Elicited item } \\
\text { 19/20 }\end{array}$ & $\begin{array}{l}\text { Inhibition of neonatal } \\
\text { neck righting }\end{array}$ & $\begin{array}{l}\text { Integración de la reacción } \\
\text { de enderezamiento cer- } \\
\text { vical }\end{array}$ & $\begin{array}{l}\text { Semantic and concep- } \\
\text { tual correspondence }\end{array}$ \\
\hline $\begin{array}{l}\text { Elicited item } \\
\text { 28/29 }\end{array}$ & $\begin{array}{l}\text { Rolling: elicited using the } \\
\text { legs }\end{array}$ & $\begin{array}{l}\text { Rolado: movimiento } \\
\text { provocado desde los } \\
\text { miembros inferiores }\end{array}$ & $\begin{array}{l}\text { Semantic and concep- } \\
\text { tual correspondence }\end{array}$ \\
\hline Elicited item 36 & Head lifting while prone & $\begin{array}{l}\text { Control cefálico en decúbi- } \\
\text { to prono }\end{array}$ & $\begin{array}{l}\text { Conceptual correspon- } \\
\text { dence }\end{array}$ \\
\hline $\begin{array}{l}\text { Elicited item } \\
\text { 38/39 }\end{array}$ & $\begin{array}{l}\text { Head turning while prone } \\
\text { in response to sound }\end{array}$ & $\begin{array}{l}\text { Seguimiento auditivo en } \\
\text { decúbito prono }\end{array}$ & $\begin{array}{l}\text { Semantic, conceptual, } \\
\text { and experiential cor- } \\
\text { respondence }\end{array}$ \\
\hline
\end{tabular}


The second stage involved quantitative and qualitative evaluation. The former was measured using judges' scores of each item on several criteria. Scoring was on a Likert scale, ranging from 1 to 4 . The scores were assessed for central tendencies and dispersion, resulting in adaptations and changes to the items. These results were satisfactory, with the criteria of relevance, sufficiency, and observability obtaining the expected results in their median, sD, and cv. Clarity was the only criterion with results outside of the expected range. Specifically $\mathrm{SD} \geq 1.0$ and $\mathrm{Cv} \geq 4.0$. This was primarily for elicited items (Table 3 ). These items were reviewed by the researchers and their adjustments requirements analyzed.

Table 3. Quantitative Evaluation of the Clarity Criterion of the PDMIc by Expert Judges

\begin{tabular}{lcc}
\hline \multirow{2}{*}{ Item } & \multicolumn{2}{c}{ Criterion: clarity } \\
\cline { 2 - 3 } & Standard deviation & Coefficient of variation \\
\hline Observed item 5 & 1.0 & Adequate \\
\hline Observed item 12 & 1.0 & Adequate \\
\hline Elicited items 19/20 & 1.0 & Adequate \\
\hline Elicited item 25 & 1.1 & Adequate \\
\hline Elicited item 26 & 1.3 & 0.4 \\
\hline Elicited item 34 & 1.0 & Adequate \\
\hline Elicited item 37 & 1.0 & Adequate \\
\hline Elicited item 40 & 1.0 & Adequate \\
\hline
\end{tabular}

A qualitative evaluation was performed for each item and comments and suggestions were made. The researchers then met to identify, and agree upon, the adjustments required. The suggestions were mainly related to the use of prepositions, punctuation marks, the decimal metric system, and the correct use of terminology relating to morphology and anatomy and the clinical field, including language referring to evaluation and neurodevelopmental interventions in the Colombian context. Each item was assessed through consideration of the statement, the starting position, the procedure, and the rating scale. Finally, after following the judges' recommendations, a consensus was reached on the wording of each item. Thus, the penultimate version of the PDMIc was obtained. Examples of items modified based on the qualitative evaluations of expert judges are depicted in Table 4 . 
Table 4. Example Items from the Test of Infant Motor Performance (TIMP) after Adaptation and Adjustment to Colombian Spanish and Qualitative Evaluation

\begin{tabular}{|c|c|c|c|}
\hline Item & Item in english & $\begin{array}{l}\text { Item translated and adapted to } \\
\text { Colombian Spanish after judge } \\
\text { consensus }\end{array}$ & $\begin{array}{l}\text { Item translated and } \\
\text { adapted to Colombian } \\
\text { Spanish: pre-final ver- } \\
\text { sion }\end{array}$ \\
\hline Observed item 9 & $\begin{array}{l}\text { Reciprocal Kicking: demon- } \\
\text { strates reciprocal kicking } \\
\text { with both legs off the sup- } \\
\text { port surface }\end{array}$ & $\begin{array}{l}\text { Pataleo recíproco - realiza pata- } \\
\text { leo recíproco con ambas extre- } \\
\text { midades inferiores separadas } \\
\text { de la superficie de apoyo }\end{array}$ & $\begin{array}{l}\text { Pataleo recíproco - realiza } \\
\text { pataleo recíproco con am- } \\
\text { bos miembros inferiores } \\
\text { separadas de la superficie } \\
\text { de apoyo }\end{array}$ \\
\hline Observed item 12 & $\begin{array}{l}\text { Oscillation of arm or leg } \\
\text { during movement: } \\
\text { more or less regularly fluc- } \\
\text { tuating movements which } \\
\text { are observed most in the } \\
\text { extended arms. A move- } \\
\text { ment cycle lasts .5-1an av- } \\
\text { erage of } 0.51 \text { sec (slower } \\
\text { than a tremor). }\end{array}$ & $\begin{array}{l}\text { Oscilación de la extremidad su- } \\
\text { perior o la inferior durante el } \\
\text { movimiento - realiza movimien- } \\
\text { tos fluctuantes más o menos } \\
\text { regulares que son observados } \\
\text { principalmente con las extremi- } \\
\text { dades superiores extendidas. } \\
\text { Un ciclo de movimiento dura } \\
\text { entre } 0.5 \text { y } 1 \text { segundo (más lento } \\
\text { que el temblor) }\end{array}$ & $\begin{array}{l}\text { Oscilación del miembro } \\
\text { superior o inferior duran- } \\
\text { te el movimiento - realiza } \\
\text { movimientos fluctuantes } \\
\text { más o menos regulares que } \\
\text { son observados principal- } \\
\text { mente con los miembros } \\
\text { superiores extendidos. } \\
\text { Un ciclo de movimiento } \\
\text { dura entre } 0,5 \text { y } 1 \text { segundo } \\
\text { (más lento que el temblor) }\end{array}$ \\
\hline Elicited item 15 & $\begin{array}{l}\text { Head control - supported } \\
\text { sitting }\end{array}$ & $\begin{array}{l}\text { Control cefálico: sentado con } \\
\text { apoyo }\end{array}$ & $\begin{array}{l}\text { Control cefálico: sedente } \\
\text { con apoyo }\end{array}$ \\
\hline Elicited item 18 & $\begin{array}{l}\text { Head control - lowered } \\
\text { from sitting }\end{array}$ & $\begin{array}{l}\text { Control cefálico: sentado a su- } \\
\text { pino }\end{array}$ & $\begin{array}{l}\text { Control cefálico: desde se- } \\
\text { dente a decúbito supino }\end{array}$ \\
\hline Elicited item 33 & $\begin{array}{l}\text { Lateral straightening of the } \\
\text { head and body with arm } \\
\text { support }\end{array}$ & $\begin{array}{l}\text { Enderezamiento lateral de la ca- } \\
\text { beza y el cuerpo con ayuda de la } \\
\text { extremidad superior }\end{array}$ & $\begin{array}{l}\text { Enderezamiento lateral de } \\
\text { la cabeza y el cuerpo con } \\
\text { soporte del miembro su- } \\
\text { perior }\end{array}$ \\
\hline
\end{tabular}

Our back-translation of the PDMIc in the third stage demonstrated that following international standards for this process had produced a successful cross-cultural adaptation of the assessment instrument.

The pilot test consisted of training professionals in the use of the assessment and their subsequent evaluation of the instrument. All of the criteria used in earlier stages were rated on scales of 1-4. Most average ratings for the various criteria were higher than 3.2/4.0, with the majority $\geq 3.8$. Overall, the evaluators found the test easy to understand with no ambiguity in the instructions, items, or scoring system. The language was seen as appropriate to the target population, and administration times were sufficient for assessing neuromotor development in children under five months of age. 


\section{Discussion}

This study describes the translation and cross-cultural adaptation of the TImp for the Colombian context, which was undertaken because of the lack of existing adapted instruments for assessing the development of infant motor skills. A standardized instrument is required to accurately assess indicators of neurological compromise displayed in motor performance for early diagnosis and timely referral to health and rehabilitation specialists.

The тімг, the Bayley Scales of Infant Development-Psychomotor Development Index ed. I (BSIDPDI-I) (6,25); the Bayley Scales of Infant Development-Psychomotor Development Index ed. II (BSID-PDI-II) (26); the Bayley Scales of Infant and Toddler Development-Total Motor Quotient ed. III (BSITD-III) (27); the Griffiths Locomotor Subscale, the AIMs, and the Peabody Developmental Motor Scales eds. I and II are among the tests used to assess this population but, unfortunately, these were originally developed in English (28-30). Therefore, studies such as this are vital for the dissemination of these tools to all of the countries that require them.

Early diagnosis and timely intervention are paramount, particularly for preterm infants, who have a high prevalence of developmental and motor development disorders, including СP (31). For this reason, guidelines have been published to assist relevant professionals in early detection (9). This includes the evaluation of motor performance in infants under five months. This cutoff is based on the established high risk period for the development of $\mathrm{CP}$ between three and four months $(6,7,9)$. Within such assessments are criteria able to predict a 95\% probability of developing ср in the following years. These guidelines emphasize the necessity for motor assessment scales applicable during this period such as the тाmp, the General Movements Assessment, and the Hammersmith Infant Neurological Examination $(9,32,33)$.

The usefulness and sensitivity of the TIMP in the evaluation of motor performance in both full-term and premature infants has been extensively studied $(23,34)$. It has demonstrated excellent discriminative and predictive capacities for the identification of infants at risk of delayed motor development (9). Evidence suggests that the TIMP is particularly sensitive in the prediction of $\mathrm{cP}$, the risk of which becomes apparent when тIMP scores are lower on items that require action against gravity and the balanced use of extension and flexion muscle activity patterns (28-35).

The TIMP can also be used in infants with type I spinal muscular atrophy and Down's syndrome as these infants show greater difficulties with early postural control and activities that require speed and balance (20,36,37). Although the тimp has sufficient reliability across the age range for which it is designed, it is also sensitive to the effects of neurodevelopmental intervention programs in infants from the 34th postconceptional week in a special care environment. This can aid in interventional development since the test can detect differences in motor performance between infants receiving the intervention and untreated control 
children. Thus, its construct validity for the detection of changes in motor performance has been demonstrated, as has its sensitivity to the effects of early intervention (37).

The above demonstrates the need for a translation and cross-cultural adaptation of the TIMP for use in the Colombian context for evaluation and clinical characterization of the target population. It can also contribute to the development of epidemiological profiles of infant motor functioning in their first months of life, affecting the health of a broad demographic of children with potential national benefits in terms of disability.

This proposal also demonstrates that the process of adapting an instrument is not just literal translation. In this case, an intralingual translation was performed because of the availability of a previous version.

The process described herein demonstrates the value of interdisciplinarity collaboration to a successful translation and adaptation of an assessment tool. The involvement of disciplinary experts utilizes their professional interest in ensuring the accuracy of the assessment. The quantitative validity of the PDMIc was excellent, with only eight of the 42 items obtaining values outside of the expected range for their sD $(<3.0)$ and cv $(\geq 1.0)$. In all instances, these were for the clarity criterion.

The тाмP has previously been translated and adapted into Portuguese. The Brazilian version was obtained from a validity and reliability study with 20 health professionals and 655 infants. The results evidenced adequate content validity due to the high levels of agreement between expert evaluations of the clarity and relevance of the items and the language used. These were determined using the content validity coefficient and Gwet's coefficient of agreement, respectively, and achieved achieving higher values than expected. There were also satisfactory results for inter-evaluator reliability $(>0.65)$, intra-evaluator reliability $(>0.97$ ), internal consistency (Cronbach's alpha $>0.71$ ), and the discriminant and predictive validity of the test to identify and predict those at risk of delayed motor development (38).

Finally, we were not restricted by limitations caused by lack of authorization from the original author or the availability of translators, expert judges, and a native translator for back-translation. This allowed us to work expediently through the stages described. It is noteworthy that an instrument such as the TIMP was not previously available in Colombian Spanish. We hope that our adaptation will assist health professionals who evaluate infant motor performance and match up to the standards of the original. The appropriate evaluation of children, timely detection of motor development disorders, early diagnosis of neuromotor pathologies, and prompt interventions can now be achieved, with potentially widespread benefits for the epidemiological profiles of health and disability in Colombia. 


\section{Conclusion}

The process of translation and cross-cultural adaptation of the timp to Colombian Spanish for the assessment of infants aged 0-4 months was successfully achieved using validated methodological standards. The PDMIc maintains idiomatic, cultural, and semantic equivalence to the original and has received positive endorsement by the primary original author. The outcome is an instrument that can be used to assess infant motor performance and identify neurological risks. The content validity has been verified, ensuring a clear and adequate structure for ease of administration. Further research will aim at determining the metric properties of validity and reliability among the Colombian infant population.

\section{Acknowledgments}

The authors express their sincere gratitude to Dr. Campbell, Professor Emeritus and first author of the original тimp, for reviewing our back-translation; and to Dr. Echeverria for providing a Spanish version of the TImP from Spain. The authors also express their gratitude to Gregory Amos Wallace for reviewing this final manuscript in English.

\section{Author contributions}

\footnotetext{
Il the authors contributed to the stages of the analytical process, preparation of the man- uscript, and approval of the final text.
}

\section{Conflicts of interest}

The authors declare no conflict of interest.

\section{References}

1. Vericat A, Orden AB. Riesgo neurológico en el niño de mediano riesgo neonatal. Acta Pediátr Méx. 2017;38(4):255-66.

2. Ylijoki MK, Ekholm E, Ekblad M, Lehtonen L. Prenatal risk factors for adverse developmental outcome in preterm infants-systematic review. Front Psychol. 2019 26;10:595. https://doi.org/10.3389/fpsyg.2019.00595 
3. Stoinska B, Gadzinowski J. Neurological and developmental disabilities in ELBW and VLBW: follow-up at two years of age. J Perinatol. 2011;31(2):137-42. https://doi. org/10.1038/jp.2010.75

4. Lenke MC. Motor outcomes in premature infants. Newborn Infant Nurs Rev. 2003;3(3):104-9.

5. Bélanger R, Mayer-Crittenden C, Minor-Corriveau M, Robillard M. Gross motor outcomes of children born prematurely in Northern Ontario and followed by a neonatal follow-up programme. Physiother Can. 2018;70(3):233-9. https://doi.rg/10.3138/ptc.2017-13

6. Campbell SK, Osten ET, Kolobe THA, Fisher AG. Development of the Test of Infant Motor Performance. Phys Medi Reha Cli of North Am. 1993;4(3):541-50. https://doi.org/10.1016/ S1047-9651(18)30569-2

7. Campbell SK, Hedeker D. Validity of the Test of Infant Motor Performance for discriminating among infants with varying risk for poor motor outcome. J Pediatr. 2001;139(4):54651. https://doi.org/10.1067/mpd.2001.117581

8. Rose RU, Westcott SL. Responsiveness of the Test of Infant Motor Performance (TIMP) in infants born preterm. Pediatr Phys Ther. 2005;17(3):219-24. https://doi.org/10.1097/01. pep.0000176575.63915.67

9. Campbell SK, The Test of Infant Motor Performance (тімP). Test User's Manual version. 2.0. Chicago: Infant Motor Performance Scales; 2005.

10. Byrne R, Noritz G, Maitre NL, NCH Early Developmental Group. Implementation of early diagnosis and intervention guidelines for cerebral palsy in a High-Risk Infant Follow-Up Clinic. Pediatr Neurol. 2017;76:66-71. https://doi.org/10.1016/j.pediatrneurol.2017.08.002

11. Beaton DE, Bombardier C, Guillemin F, Ferraz MB. Guidelines for the process of cross-cultural adaptation of self-report measures. Spine (Phila Pa. 1976) 2000;25(24):3186-91. htpps://doi.org/10.1097/00007632-200012150-00014.

12. Escobar Bravo MÁ. Adaptación cross-cultural de instrumentos de medida relacionados con la salud. Enferm Clin. 2004;14(2):102-6.

13. Balluerka N, Gorostiaga A, Alonso-Arbiol I, Haranburu M. La adaptación de instrumentos de medida de unas culturas a otras: una perspectiva. Psicothema. 2007;19(1):124-33.

14. Muñiz J, Elosua P, Hambleton RK, International Test Commission. Directrices para la traducción y adaptación de los tests: segunda edición. Psicothema. 2013;25(2):151-7.

15. Valdelamar-Jiménez J, Sánchez-Pedraza R. Traducción y adaptación cross-cultural de la escala Life Orientation Test-Revised para medir optimismo disposicional en cuidadores de pacientes con cáncer en Colombia. Rev Fac Nac Salud Publ. 2017 May;35(2):2016-224. https://doi.org/10.17533/udea.rfnsp.v35n2a06

16. Garcimartin P, Pardo-Cladellas Y, Verdú-Rotellar JM, Delgado-Hito P, Astals-Vizcaino M, Comin-Colet J. Cross-cultural adaptation into Spanish of the Patient empowerment in long-term conditions questionnaire. Aten Primaria. 2019;51(1):24-31. htpps://doi. org/10.1016/j.aprim.2017.09.009

17. Gaite L, Ramírez N, Herrera S, Velásquez JL. Traducción y adaptación transcultural de instrumentos de evaluación en Psiquiatría: Aspectos metodológicos. Arch Neurobiol. 1997;60(2):91-11. 
18. Cabré Castellví MT. Theories of terminology. Terminol Int J Theor Appl Issues Spec Commun. 2003 Dec 31;9(2):163-99.

19. Echevarria Ulloa M. Adaptacion transcultural y version espanola de la prueba de rendimiento motor infantil (TIMP). [tesis doctoral].Madrid: Universidad Complutense de Madrid; (2017) Available from https://eprints.ucm.es/id/eprint/42956/

20. Campos De AC, Santos DCC, Rocha NACF. Children Y. Motor performance of children with Down syndrome and typical development at 2 to 4 and 26. Pediatr Phys Ther. 2018;27(2):135-41. https://doi.org/10.1097/PEP.0000000000000120

21. Spittle AJ, Doyle LW, Boyd RN. A systematic review of the clinimetric properties of neuromotor assessments for preterm infants during the first year of life. Dev Med Child Neurol. 2008;50(4):254-66. https://doi.org/10.1111/j.1469-8749.2008.02025.x

22. Campbell SK, Kolobe THA. Concurrent validity of the Test of Infant Motor Performance with Alberta Infant Motor Scale. Pediatr Phys Ther. 2000;12(1):2-9. https://doi. org/10.1080/01942630802224892

23. Coker-Bolt P, Woodbury ML, Perkel J, Moreau NG, Hope K, Brown T, et al. Identifying premature infants at high and low risk for motor delays using motor performance testing and MRS. J Pediatr Rehabil Med. 2014;7(3):219-32. https://doi.org/10.3233/PRM-140291

24. Campbell SK, Kolobe TH, Wright BD, Linacre JM. Validity of the Test of Infant Motor Performance for prediction of 6-, 9- and 12-month scores on the Alberta Infant Motor Scale. Dev Med Child Neurol. 2002;44(4):263-72. https://doi.org/10.1017/s0012162201002043

25. Bayley N. Bayley Scales of Infant Development [Measurement instrument]. San Antonio, тх: The Psychological Corporation; 1969

26. Bayley N. Bayley Scales of Infant Development (2nd ed) [Measurement instrument]. San Antonio, Tx: The Psychological Corporation; 1993.

27. Bayley N. Bayley scales of infant and toddler development. 3. ${ }^{\mathrm{a}}$ ed. San Antonio: Pearson; 2006.

28. Piper M, Darrah J. Motor assessment of the developing infant. Philadelphia: W. B. Saunders Company; 1994.

29. Folio R, Fewell R. Peabody developmental motor scales and activity cards manual. Allen, Tx: DLM Teaching Resources; 1983.

30. Spittle OJ, Anderson P, Boyd R, Doyle L. Early developmental intervention programs post hospital discharge to prevent motor and cognitive impairments in preterm infants What's new Dates Text of review Synopsis. Cochrane Database Syst Rev. 2009;1(11):1-56. https://doi.org/10.1002/14651858.CD005495.pub2

31. Rana M, Upadhyay J, Rana A, Durgapal S, Jantwal A. A systematic review on etiology, epidemiology, and treatment of cerebral palsy. Int J Nutr Pharmacol Neurol Dis. 2017;7:76-83. https://doi.org/10.4103/ijnpnd.ijnpnd_26_17

32. Einspieler C, Prechtl HF, Bos AF, Ferrari F, Cioni G. Prechtl's Method on the Qualitative Assessment of General Movements in Preterm, Term and Young Infants [ebook]. London: Mac Keith Press; 2008. 
33. Dubowitz L, Ricciw D, Mercuri E. The Dubowitz neurological examination of the fullterm newborn. Ment Retard Dev Disabil Res Rev. 2005;11(1):52-60. https://doi.org/10.1002/ mrdd.20048

34. Barbosa VM, Campbell SK, Smith E, Berbaum M. Comparison of Test of Infant Motor Performance (TIMP) item responses among children with cerebral palsy, developmental delay, and typical development. Am J Occup Ther. 2005;59(4):446-56. https://doi. org/10.5014/ajot.59.4.446

35. Finkel RS, Hynan LS, Glanzman AM, Owens H, Nelson L, Cone SR, et al. The test of infant motor performance: Reliability in spinal muscular atrophy type i. Pediatr Phys Ther. 2008;20(3):242-6.

36. Moriyama CH, Massetti T, Crocetta TB, Silva Da TDD, Mustacchi Z, Guarnieri R, et al. Systematic review of the main motor scales for clinical assessment of individuals with Down syndrome. Dev Neurorehabil. 2020;23(1):39-49. https://doi.org/10.1080/1751842 3.2019.1687598

37. Campbell SK. Test-retest reliability of the Test of Infant Motor Performance. Pediatr Phys Ther. 1999;11(2):60-6.

38. Chiquetti EMdos S, Valentini NC, Saccani R. Validation and reliability of the test of infant motor performance for Brazilian infants. Phys Occup Ther Pediatr. 2020;0(0):1-16. https://doi.org/10.1080/01942638.2020.1711843 